\title{
Diversity and Abundance of Mycorrhizal Fungi Spores in Gmelina arborea Stand
}

\author{
Gusmiaty $^{1}$, Siti Halimah Larekeng ${ }^{2}$, Lily Istigfaiyah ${ }^{3}$ \\ ${ }^{1,2,3}$ Biotechnology and Tree Breeding Laboratory, Department of Forestry, Faculty of Forestry, \\ Universitas Hasanuddin, Indonesia. 90245 \\ \{umyhody@gmail.com¹, sitih5h.82@gmail.com², lilyansar@outlook.com ${ }^{3}$ \}
}

\begin{abstract}
Mycorrhizas are the symbiotic associations between plant and fungi. Mycorrhizal fungi always associate with the roots of higher plants, indeed over $90 \%$ of plant species, including forest trees, wild grasses and many crops. This study aims to determine the type of spores associated with Gmelina arborea stands. This research consisted of collecting root samples, identifying fungal spores in root samples and observing arbuscular mychorriza fungal infections. The results showed that the types of spores observed in root samples were Glomus, Gigaspora, and Scutellospora. The percentage of colonization on both sites is medium.
\end{abstract}

Keywords: Mycorrhiza, Vesicular, Arbuscular, Gmelina arborea.

\section{Introduction}

Melina (Gmelina arborea Roxb) is one type of tree that has the potential to be developed in industrial plantations and community plantations [1]. Melina has rapid growth (fast growing species) and uses as raw material for the pulp industry, materials for making particle boards, plywood cores, matches, containers and wood craft materials [2]. The benefits of Melina cultivation are easy to plant maintenance, not complicated planting techniques and good economic value [3].

One effort to support Melina's growth is to increase the fertility of the soil which can be done by giving organic fertilizer. However, in large-scale planting, the fertilizer needed is relatively large and expensive. Therefore, an alternative method is needed to increase soil fertility through mycorrhizal utilization. True mycorrhiza comes from the Greek language, mykes, which means mushroom, and rhiza means root, so literally means root mushroom. Mycorrhizal fungi can associate with over $90 \%$ of higher plant species (including agricultural

crops) and are found in soil of all continents from alpine lands to tropical forests and from grasslands to croplands [4,5]. Mycorrhiza can colonize and develop symbiotic mutualism with plant roots, so it can increase plant growth, and help suppress the development of several soil pathogens. Mycorrhizal infection can increase plant growth and its ability to utilize nutrients, especially the elements $\mathrm{P}, \mathrm{Ca}, \mathrm{N}, \mathrm{Cu}, \mathrm{Mn}, \mathrm{K}$, and $\mathrm{Mg}[6,7,8,9]$. This is caused by mycorrhizal colonization in plant roots can expand the field of root uptake [10]. 
Arbuscular mycorrhizas are the most common type of mycorrhizas, involving primitive aseptate fungi from Glomeromycota phylum. At the present time, arbuscular mycorrhizal fungi have been classified into four orders (Diversisporales, Glomerales, Archaeosporales and Paraglomerales) of the Glomeromycota phylum [11]. Research on arbuscular mycorrhizal identification in various types of community forest ecosystems in South Sulawesi showed that there were three types of spores found, namely the genus Glomus, Gigaspora and Acaulospora [12]. [13] conducted research on the identification of mycorrhizae in teak forests in Barru Regency. The results showed that there were four types of spores found, namely Gigaspora, Glomus, Acaulospora, and Scutellospora.

Research on the identification of mycorrhizae in Melina plants in South Sulawesi has not been reported, so research is needed on the types of mycorrhiza associated with Melina stands. This research is expected to be the basis of mycorrhizal utilization in increasing Melina plant growth.

\section{Material and Methods}

\section{Root sample collection}

Root sampling was carried out at five points for each location. Determination of sampling points is done by purposive sampling method. Roots are taken in four directions for each point with a depth of $0-20 \mathrm{~cm}$. The sample root is then put into a plastic clip and labeled.

\section{Isolation, Identification and Root colonization observation}

The technique of observing mycorrhizal colonization in roots using the infected root length method [14] while identification of mycorrhizal spores was carried out using the root coloring method [15].

The first step is to choose the delicate roots of the plant and then wash the roots clean. The root sample is then soaked in FAA solution for 24 hours then discard the FAA solution and wash the root sample thoroughly. Root samples were immersed in $10 \% \mathrm{KOH}$ solution for 24 hours then disposed of the $\mathrm{KOH}$ solution and washed the roots clean. Root samples were immersed in $10 \% \mathrm{H}_{2} \mathrm{O}_{2}$ solution for 24 hours then disposed of $\mathrm{H}_{2} \mathrm{O}_{2}$ solution and washed the roots thoroughly. Root samples were immersed in $2 \% \mathrm{HCl}$ solution for 24 hours then disposed of $\mathrm{HCl}$ solution and washed the roots thoroughly. The roots are divided into two, one part is dried for 24 hours for the method of identification of mycorrhiza, and the other part is immersed in a staining solution for 24 hours for the method of observing root colonization. Observation of colonization was carried out by cutting five root samples with a length of $1 \mathrm{~cm}$ in each part of the root (root base, middle root, root tip, end of root branch and base of root branch). The roots are arranged in glass preparation and observed under a microscope.

Root samples for observation of spores were blended until smooth and soaked in a staining solution for 24 hours. The next step is to choose the three smoothest roots and arrange them on the glass preparation. Preparations were observed under a microscope and identified using the INVAM guide. 


\section{The observed variable}

The variable observed in the study were :

1. Morphology of mycorrhizal spores

Spores found in root samples were observed in the morphological characters in the form, color, hyphae holder and spore ornaments. Genus Spora Mikoriza

2. Relative Abundance of Spores

The relative abundance of spores is calculated based on formulas [16]:

Relative abundance $=\underline{\text { Number of genus }} \times 100 \%$

$$
\text { Total of spore }
$$

3. Root infections

Root colonization is seen based on the percent of root infection by mycorrhizal structure calculated based on the formula [17]:

Root infection $=$ Number of infected root $\times 100 \%$

total observed field

\section{Data analysis}

Data from observations are presented in the form of tabulation and image data. The classification criteria for the number of infected roots are classified into five classes and presented [18] in Table 1.

Table 1. Classification of Number of Root Infections

\begin{tabular}{cc}
\hline Percentage of Colonization & Kategori \\
\hline $0-5$ & Very low \\
$6-25$ & Low \\
$26-50$ & Moderate \\
$50-75$ & High enough \\
$75-100$ & High \\
\hline
\end{tabular}

\section{Results and Discussion}

The results of the observation showed that there were three types of spores found in root samples, namely Glomus, Scutellospora and Gigaspora. The type of spore has different morphological characteristics and relative abundance at each location. The types of spores found in root samples at each study location are presented in Table 2.

Table 2. Types of Spores Found in Root Samples in Each Study Site

\begin{tabular}{cc}
\hline Research site & Genus Spora \\
\hline Balong village & Glomus \\
Bulukumba district & Scutellospora \\
& Gigaspora \\
Lamatti Riawang village & Glomus \\
Sinjai district & Scutellospora \\
\hline
\end{tabular}


Based on Table 2, there are differences in the spore genus found in the root samples of both locations. Glomus and Scutellospora can be found in root samples of both locations while Gigaspora is only found in Bulukumba root samples. According to [19], the location and rhizosphere factors greatly influence species diversity and mycorrhizal population. This is consistent with [20] study stating that the type of mycorrhizae that are associated with Eboni (Diospyros celebica) in Bengo-Bengo Education Forest is Gigaspora and Acaulospora, while [21] study states that the type of mycorrhiza associated with Cempaka plants (Elmerillia ovalis) in North Toraja community forests are Glomus and Gigaspora species. The difference in the spore genus is also caused by differences in spore tolerance to soil type, organic matter content, light intensity and altitude above sea level [17]. The forms of spores found in root samples are presented in Figure 1.

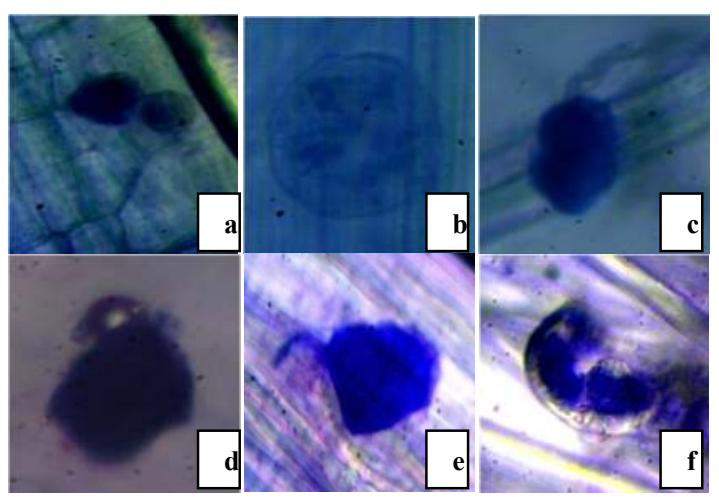

Fig 1. Identification of mycorrhizal spores on root samples (a) (b) and (c) Glomus spores, (d) and (e) Scutellospora spores and (f) Gigaspora spores

Based on Figure 1, spores were found to have different morphological characteristics. Morphological characteristics were observed in the form, color, hyphae holder and spore ornaments. There are three genera found, namely Glomus, Gigaspora and Scutellospora.

Glomus spores were found to be round (Figure 1a and 1b) and oval (Figure 1c) and black (Figure 1a), hyaline (Figure 1b) and blue (Figure 1c). The spores found were those that had hyphae seats (Figures 1a and 1c) and did not have hyphae (Figure 1b). The spore was formed singly (Figures 1b and 1c) and in groups (Figure 1a). According to [22], Glomus is a genus that has a widespread, and quite high adaptation to environmental conditions [23]. One of the adaptations carried out by the genus Glomus is faster spore germination, which only requires 46 days. The Glomus genus germinates faster because the smaller spore size causes the hydration phase to occur very quick so that the enzyme activity associated with the germination process will take place faster [24]. Scutellospores were found to have irregular shapes (Figures 1d and 1e) with black (Figures 1d) and blue (Figure 1e). The spores observed have hyphae seats. Scutellospora is usually found more in acidic soil conditions [25]. Gigaspora is found to be round and irregular and black (Figure 1f). Spores are produced singly and do not form the inner layer. There is no hyphae attached so that the bulbous suspensor is not visible.

Relative abundance is one determinant of qualitative assessment of spores. Relative abundance is the number of genera found at the observation location divided by the total spores 
at the observation location multiplied by $100 \%$. This data shows the amount of abundance of a type of spore in an observation location. The relative abundance of mycorrhizal spores in root samples of each location was different. The table of relative abundance of spores is presented in Table 3.

Table 3. Relative Abundance of Mycorrhizal Spores on Root Samples in Each Study Site

\begin{tabular}{|c|c|c|c|}
\hline \multirow{2}{*}{ Study site } & \multicolumn{3}{|c|}{ Relative Abundance (\%) } \\
\hline & Glomus & Gigaspora & Scutellospora \\
\hline Balong village & 62,5 & 12,5 & 25 \\
\hline Bulukumba district & & & \\
\hline $\begin{array}{c}\text { Lamatti Riawang } \\
\text { village }\end{array}$ & 90 & - & 10 \\
\hline Sinjai district & & & \\
\hline
\end{tabular}

Based on Table 3, Glomus has the highest relative abundance in both locations. The second genus that dominates both locations is Scutellospora. Gigaspora was only found in the root sample of Balong Village while in the root sample of Lamatti Riawang Village Gigaspora spores were not found. Glomus abundance is large because Glomus has a widespread and high adaptation to its environmental conditions [22]. This is by the results of the research by [26] which showed that Glomus had the highest percentage of abundance in plants $(75.39 \%)$, followed by successively with Acaulospora (8.62\%), Scutellospora (8.67\%). ) and Gigaspora $(5.83 \%)$. The differences in the spores found were related to differences in sampling locations and rhizosphere. According to [19], differences in location will result in differences in soil types as limiting factors that influence the presence of the spore genus.

\section{Percentage of root colonization}

The results showed that the average value of the percentage of mycorrhizal colonization in both locations was different. The average percentage of mycorrhizal colonization is presented in Figure 2.

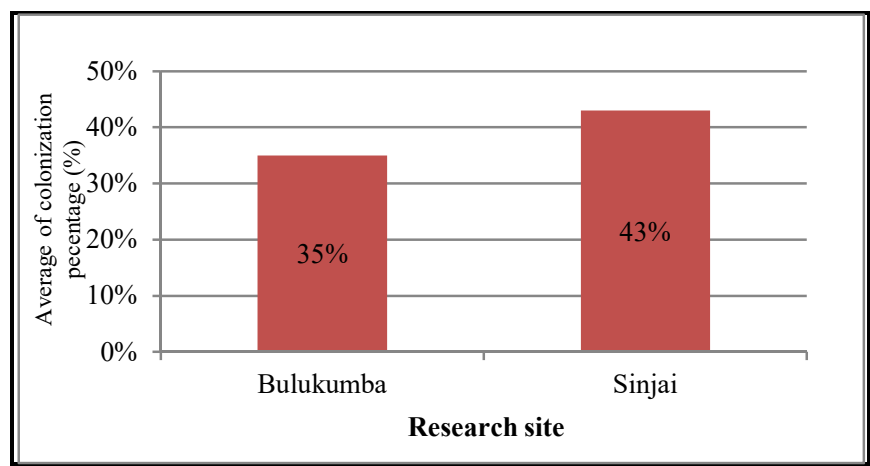

Fig 2. The Average of Percentage of Mycorrhizal Colonization in Root Samples in Bulukumba District and Sinjai District 
Based on Figure 2, the average percentage of root colonization in both locations is classified as moderate. The percentage of colonization in Sinjai is slightly higher when compared to the Bulukumba region. This is because the rainfall conditions for sampling in both locations are different. The location in Bulukumba is carried out during the dry season, while in Sinjai it is carried out during the rainy season. According to [27], in conditions of high rainfall, generally, the percentage of colonization increases and spore formation decreases, whereas in the dry season new spore formation will increase. Other factors that influence the percentage of root infections are soil texture, soil $\mathrm{pH}$, host plants and tillage.

\section{Conclusion}

Based on the results of the research conducted, it can be concluded that the spore genus associated with root Melina in Bulukumba and Sinjai Districts is Glomus, Gigaspora, and Scutellospora. Glomus has a relatively high abundance compared to other genera. The average percentage of mycorrhizal colonization in the study location is classified as moderate

\section{References}

[1] Rengganis, D.: Studi Keanekaragaman Genus Mikoriza Arbuskula di Sekitar Perakaran Pohon Jabon (Anthocephalus cadamba) Alami. Skripsi. Departemen Silvikultur Fakultas Kehutanan Institut Pertanian Bogor (2013)

[2] Sudomo, A., A. Hani dan E. Suhaendah : Pertumbuhan Semai Gmelina arborea Linn dengan Pemberian Mikoriza, Pupuk Organik Diperkaya dan Cuka Kayu. Jurnal Pemuliaan Tanaman Hutan, 1(2) , 1-6 (2007)

[3] Misnawati, Y. dan Rahmawati : Pertumbuhan Stump Gmelina (Gmelina arborea Roxb.) pada Berbagai Perbedaan Lama Waktu Penyimpanan. Warta Rimba, 2(2), 133-140 (2014)

[4] Mbodj, D., Effa-Effa, B., Kane, A., Manneh, B., Gantet, P., Laplaze, L., Diedhiou, A.G., Grondin, A.: Arbuscular mycorrhizal symbiosis in rice: Establishment, environmental control and impact on plant growth and resistance to abiotic stresses. Rhizosphere 812 26https://doi.org/10.1016/j.rhisph.2018.08.003 (2018)

[5] Smith, S.E., Read, D. : Mycorrhizal Symbiosis. https://doi.org/10.1016/B978-0-12-3705266.X5001-6 (2008).

[6] Pulungan, A.S.: Biodiversity of Mycorrhiza in Red Pepper Rhizosfer. Jurnal Biosains, 1(3), 125-129 (2015)

[7] Choi, J., Summers, W., Paszkowski, U. : Mechanisms underlying establishment of arbuscular mycorrhizal symbioses. Annu. Rev. Phytopathol. 56, 1-26. https://doi.org/10.1146/annurev-phyto-080516-035521 (2018)

[8] Saini, I., Aggarwal, A., Kaushik, P. : Inoculation with Mycorrhizal Fungi and Other Microbes to Improve the Morpho-Physiological and Floral Traits of Gazania rigens (L.) Gaertn. Agriculture, 9, 51. doi:10.3390/agriculture9030051 (2019)

[9] Weisany,W., Raei, Y., Salmasi, S.Z., Sohrabi, Y., Ghassemi-Golezani, K. : Arbuscular mycorrhizal fungi induced changes in rhizosphere, essential oil and mineral nutrients uptake in dill/common bean intercropping system. Ann. Appl. Biol., 169, 384-397 (2016)

[10] Sari, R.R. dan D. Ermavitalini : Identifikasi Mikoriza dari Lahan Desa Cabbiya Pulau Poteran, Sumenep Madura. Jurnal Sains dan Seni Pomits 3(2) , 2337-3520 (2014) 
[11] Redecker, D., Schüßler, A., Stockinger, H., Stürmer, S.L., Morton, J.B., Walker, C. : An evidence-based consensus for the classification of arbuscular mycorrhizal fungi (Glomeromycota). Mycorrhiza 23, 515-531.https://doi.org/10.1007/s00572-013-0486-y (2013)

[12] Gusmiaty., M. Restu., S.A. Paembonan., A. Arif dan S.H. Larekeng : Mycorrhiza Diversity from Various Private Forest Ecosystem Types in South Sulawesi. Proseding International Conference on Lifes Sciences and Biotechnology. Jember, 185 - 188 (2015)

[13] Danda, D.: Identifikasi Cendawan Mikoriza Arbuskula pada Hutan Rakyat Jati (Tectona grandis) di Kabupaten Barru. Skripsi. Fakultas Kehutanan Universitas Hasanuddin, Makassar (2015)

[14] Husna : Studi Diversitas Cendawan Mikoriza Arbuskula (mikoriza) Asal Sulawesi Tenggara. Proseding Seminar Teknologi Produksi dan Pemanfaatan Inokulan Endomikoriza dan Ektomikoriza untuk Tanaman Pertanian, Perkebunan dan Kehutanan, Bandung. (2003)

[15] Nusantara, A.S., Y.H. Bertham dan I. Mansur : Bekerja dengan Fungi Mikoriza Arbuskula. Seameo Biotrop, Bogor (2012)

[16] Shi, Z.Y., Y.L. Chen., G. Feng., R.J. Liu dan P. Christie : Arbuscular Mycorrhizal Fungi Associated with the Meliaceae on Hainan Island, China, Mycorrhiza, 16, 81 - 87 (2004)

[17] Setiadi, Y.: Mikoriza dan Pertumbuhan Tanaman. Departemen Pendidikan dan Kebudayaan, Direktorat Jenderal Pendidikan Tinggi Pusat Antar Universitas IPB. Bogor (1992)

[18] Lukman, R. dan S. Khotimah : Jamur Mikoriza Vesikular Arbuskular (CMA) pada Rhizosfer Tanaman Langsat (Lansium domesticum Corr.) di Lahan Gambut. Jurnal Protobiont, 4(3), 89-97 (2015)

[19] Sundari, S., T. Nurhidayati dan I. Trisnawati : Isolasi dan Identifikasi Mikoriza Indigenous dari Perakaran Tembakau Sawah (Nicotiana tabacum L.) di Area Persawahan Kabupaten Pamekasan Madura. Jurusan Biologi, Fakultas Matematika dan Ilmu Pengetahuan Alam Institut Teknologi Sepuluh Nopember, Surabaya (2011)

[20] Defky : Identifikasi Jenis Mikoriza pada Tanaman Ebony (Diospyros celebica Bakh.). Skripsi. Program Studi Kehutanan Fakultas Kehutanan Universitas Hasanuddin, Makassar (2017)

[21] Randabunga, D.: Identifikasi Fungi Arbuskular Mikoriza pada Hutan Rakyat Cempaka (Elmerillia ovalis) di Kabupaten Toraja Utara. Skripsi. Program Studi Kehutanan Fakultas Kehutanan Universitas Hasanuddin, Makassar (2015)

[22] Tarmedi, E.: Keanekaragaman Cendawan Mikoriza Arbuskula di Hutan Sub Pegunungan Kamojang Jawa Barat. Skripsi. Program Studi Budidaya Hutan Fakultas Kehutanan Institut Pertanian Bogor, Bogor (2006)

[23] Puspitasari, D., K.I Purwani dan A. Muhibbudin : Eksplorasi Vesicular Arbuscular Mycorrhiza (VAM) Indigenous pada Lahan Jagung di Desa Torjun, Sampang Madura. Jurnal Sains dan Seni ITS, 1(1) (2012)

[24] Saputra, B., R. Linda dan S. Khotimah : Jamur Mikoriza Vesikular Arbuskular (MVA) pada Tiga Jenis Tanah Rhizosfer Tanaman Pisang Nipah (Musa paradisiaca L. var. nipah) di Kabupaten Pontianak. Jurnal Protonbiont, 4(1), 160 - 169 (2015)

[25] Simangunsong, S.A.: Pengaruh Pemberian Berbagai mikoriza dan Pupuk Kandang Ayam Pada Tanaman Tembakau Deli Terhadap Serapan P dan Pertumbuhan di Tanah Inceptisol Sampali. Skripsi. Departemen Ilmu Tanah Fakultas Pertanian Universitas Sumatera Utara, Padang (2006) 
[26] Datta, P dan M. Kulkarni : Arbuscular Mycorrhizal Fungal Diversity in Sugarcane Rhizosphere in Relation with Soil Properties. Notulae Scientia Biologicae, 4(1), 66-74 (2012)

[27] Delvian dan Elvianti.: Variasi Musiman dan Distribusi Fungi Mikoriza Arbuskula di Areal Pertanaman Sawit. National Seminar of Biodiversity, Depok (2016) 